\title{
Hyponatremia - A Rare but Serious Complication of Amiodarone: A Case Report and Review of the Literature
}

\author{
Linh Pham ${ }^{a}$ Andrea J. Shaer ${ }^{a}$ Thomas Marnejon ${ }^{a, b}$ \\ ${ }^{\mathrm{a}}$ Department of Medicine, St. Elizabeth Health Center, Youngstown, Ohio, and \\ ${ }^{b}$ Department of Medicine, Northeast Ohio Medical University, Rootstown, Ohio, USA
}

\section{Key Words}

Amiodarone - Hyponatremia - Syndrome of inappropriate antidiuretic hormone secretion ·

Side effect

\begin{abstract}
Introduction: Hyponatremia secondary to the syndrome of inappropriate antidiuretic hormone secretion (SIADH) during amiodarone therapy is a rare but potentially lethal adverse effect. We report a case of severe hyponatremia associated with amiodarone, and discuss its clinical implications. Case Report: An 84-year-old Caucasian man with a past medical history of hypertension and diabetes was admitted to the hospital with a non-ST elevation myocardial infarction. He underwent coronary artery bypass graft and developed atrial fibrillation on postoperative day 2. A loading dose of amiodarone followed by a maintenance dose was started. The serum sodium level was $136 \mathrm{mmol} / \mathrm{l}$ at discharge and subsequently decreased to $105 \mathrm{mmol} / \mathrm{l} 11$ days later, at which time the patient represented with altered mental status. The diagnosis of SIADH was made based on euvolemic hypoosmotic hyponatremia, lack of any other medication known to cause SIADH and urine that was less than maximally dilute. The serum sodium increased gradually to $123 \mathrm{mmol} / \mathrm{l}$ after $36 \mathrm{~h}$ of treatment with hypertonic saline, demeclocycline and fluid restriction. Conclusion: SIADHinduced hyponatremia associated with amiodarone occurs rarely. Since severe hyponatremia is associated with significant neurological damage and mortality, clinicians should carefully monitor serum sodium during amiodarone therapy.
\end{abstract}

Thomas Marnejon, DO

Department of Medicine, St. Elizabeth Health Center

1044 Belmont Avenue

Youngstown, OH 44504 (USA)

E-Mail thomas_marnejon@hmis.org 


\section{Introduction}

Amiodarone is an effective antiarrhythmic agent with well-known noncardiac toxicities including pulmonary fibrosis, hypo- or hyperthyroidism, liver function abnormalities, corneal deposits and photosensitivity. Hyponatremia secondary to the syndrome of inappropriate antidiuretic hormone secretion (SIADH) during amiodarone therapy is a rare but potentially lethal adverse effect of this drug. We describe the lowest reported serum sodium level due to amiodarone therapy. We also review the previously reported cases of SIADH-induced hyponatremia secondary to amiodarone and discuss salient clinical implications.

\section{Case Report}

An 84-year-old Caucasian man with a past medical history of hypertension and diabetes was admitted to the hospital with a non-ST elevation myocardial infarction. Urgent left heart catheterization showed multivessel disease, and the patient subsequently underwent coronary artery bypass graft. On postoperative day 2 , the patient developed atrial fibrillation with rapid ventricular response. He was started on intravenous amiodarone with a loading dose of $150 \mathrm{mg}$, followed by a continuous infusion of $1 \mathrm{mg} / \mathrm{min}$. After $24 \mathrm{~h}$, intravenous amiodarone was discontinued and switched to $400 \mathrm{mg}$ orally every $8 \mathrm{~h}$. The oral dose of amiodarone was tapered over 7 days to $400 \mathrm{mg}$ daily. The patient's atrial fibrillation converted to normal sinus rhythm after the loading dose of amiodarone. He was discharged on postoperative day 7 on amiodarone $400 \mathrm{mg}$ daily. At the time of discharge, his serum sodium was $136 \mathrm{mmol} / \mathrm{l}$.

The patient then presented to the emergency room 11 days later due to altered mental status, weakness and loss of appetite. He was drowsy but arousable. Physical examination revealed normal vital signs and euvolemic status. There was no orthostatic blood pressure change. A neurological examination showed no focal deficit. Laboratory data revealed a serum sodium level of $105 \mathrm{mmol} / \mathrm{l}$. Renal and liver function tests were normal. Thyroid stimulating hormone and cortisol levels were $0.7 \mu \mathrm{IU} / \mathrm{ml}$ (normal range: $0.350-5.000$ $\mu \mathrm{IU} / \mathrm{ml}$ ) and $16 \mu \mathrm{g} / \mathrm{dl}$ (normal range: 3.09-22.40 $\mu \mathrm{g} / \mathrm{dl}$ ), respectively. Serum osmolality was $228 \mathrm{mOsm} / \mathrm{kg}$ and urine osmolality was $251 \mathrm{mOsm} / \mathrm{kg}$. It was noted that the patient was on furosemide $20 \mathrm{mg}$ daily prior to his admission. Repeat testing after discontinuation of furosemide revealed a serum osmolality of $256 \mathrm{mOsm} / \mathrm{kg}$ and a urine osmolality of 506 $\mathrm{mOsm} / \mathrm{kg}$. The fractioned excretion of sodium was greater than $1 \%$ and the urine sodium was $124 \mathrm{mmol} / \mathrm{l}$.

The diagnosis of SIADH was made based on euvolemic hypoosmotic hyponatremia, with a urine osmolality greater than the serum osmolality, urine sodium level greater than 40 $\mathrm{mmol} / \mathrm{l}$, normal thyroid and adrenal function and the absence of other medications known to cause SIADH. The patient was initially treated with hypertonic (3\%) saline. His serum sodium increased gradually to 117 and $123 \mathrm{mmol} / \mathrm{l}$ after 36 and $48 \mathrm{~h}$ of treatment, respectively. Hypertonic saline was discontinued after 3 days, and demeclocycline was added, together with fluid restriction. The patient's mental status improved and his serum sodium normalized after 10 days of treatment (fig. 1). 


\section{Discussion}

SIADH was first reported by Schwartz et al. in 1957 [1] in patients with bronchogenic carcinoma and meningitis. In 1971, four cases of chlorpropamide-induced hyponatremia were described by Weissman et al. [2]. Since then, a variety of drugs have been added to the list of drugs that cause SIADH [3].

Amiodarone, a benzofuran derivative, was developed by a Belgian company (Labaz) in 1961 by the chemists Tondeur and Binon as an antianginal drug [4]. A few years later, amiodarone was widely used as an antiarrhythmic drug in Europe and other countries. It was not until the mid-1980s that amiodarone was approved by the FDA as a class III antiarrhythmic agent in the United States. In 1996, the first case of amiodarone-induced hyponatremia was reported [5]. Since then, a total of 10 cases of amiodarone-induced SIADH have been published in the literature (table $1 ;$ [6-13]).

The mechanism of SIADH-induced hyponatremia secondary to amiodarone is unclear [11]. It could possibly be due to the independent secretion of arginine vasopressin relative to plasma osmolality, full suppression of secretion of this hormone or mutations of the aquaretic (i.e. water channel regulating) vasopressin receptor [3]. Most medications cause SIADH either by sensitizing the kidneys to antidiuretic hormone, by stimulating the release of antidiuretic hormone or by both [14]. Of note, Shavit and Sherer [11] speculated that amiodarone might induce SIADH by its channel-modulating properties on either renal or neural tissues.

Among the 10 reported cases, the majority of patients were elderly men ( 8 out of 10) with a median age of 69 years. Age and sex may be contributing factors to amiodaroneinduced SIADH. The elderly appear to be particularly at risk for drug-induced SIADH [14]. In a study on 736 cases of selective serotonin re-uptake inhibitor-induced SIADH, 75\% of patients were over 65 years of age [15].

The duration of time from the initiation of amiodarone to the development of SIADH varied from 3 days to 6 months in the reported cases. The onset of hyponatremia ranged from day 3 to day 11 in patients who received loading doses of amiodarone. In contrast, hyponatremia occurred at 14 days to 6 months in patients receiving maintenance doses. In 7 cases, the serum sodium level normalized within 7-14 days after discontinuation of amiodarone and fluid restriction. It appears that amiodarone-induced SIADH is more prevalent after a loading dose of the drug. However, because of the long half-life of amiodarone, the cumulative effect on the development of SIADH remains undefined.

Acute, severe hyponatremia (serum sodium $<125 \mathrm{mmol} / \mathrm{l}$ ) has been associated with serious sequelae, including confusion, hallucinations, seizures, coma and respiratory failure leading to death [3]. The degree of hyponatremia in the majority of reported cases of amiodarone-induced SIADH was 110-120 mmol/l. In 2 cases, Paydas et al.'s [10] and our case, serum sodium levels were less than $110 \mathrm{mmol} / \mathrm{l}$ (107 and $105 \mathrm{mmol} / \mathrm{l}$, respectively). It is important to note that in hospitalized patients, the mortality was $28 \%$ in patients with serum sodium $<125 \mathrm{mmol} / \mathrm{l}$ and $50 \%$ in patients with serum sodium level $<115 \mathrm{mmol} / \mathrm{l}$ [16]. Therefore, amiodarone-induced SIADH is a rare but lethal adverse effect, which occurs predominantly in elderly patients, who typically have multiple comorbidities, especially cardiovascular diseases, for which the drug is used.

The only definitive treatment of SIADH is the elimination of its underlying cause [3, 14]. In all but 3 cases, amiodarone was discontinued and fluid restriction was instituted. In the remaining cases, the dose was decreased. One patient required hemodialysis due to decreasing serum sodium coupled with the development of altered mental status [12]. 
Pham et al.: Hyponatremia - A Rare but Serious Complication of Amiodarone: A Case Report and Review of the Literature

To our knowledge, a total of 10 cases of amiodarone-induced SIADH have been reported thus far in the literature. This adverse effect can occur as early as 3 days after receiving a loading dose or as late as 6 months in patients on maintenance doses. Age and male sex appear to be contributing factors. The severity of hyponatremia is directly correlated with increased mortality in the hospitalized patient. Therefore, clinicians should be aware of this important complication when treating patients with amiodarone.

\section{References}

-1 Schwartz WB, Bennett W, Curelop S, Bartter FC: A syndrome of renal sodium loss and hyponatremia probably resulting from inappropriate secretion of antidiuretic hormone. Am J Med 1957;23:529-542.

$\longrightarrow 2$ Weissman PN, Shenkman L, Gregerman RI: Chlorpropamide hyponatremia: drug-induced inappropriate antidiuretic-hormone activity. N Engl J Med 1971;284:65-71.

3 Ellison DH, Berl T: Clinical practice. The syndrome of inappropriate antidiuresis. N Engl J Med 2007;356:2064-2072.

-4 Deltour G, Binon F, Tondeur R, Goldenberg C, Henaux F, Sion R, Deray E, Charlier R: Studies in the benzofuran series. VI. Coronary-dilating activity of alkylated and aminoalkylated derivatives of 3benzoylbenzofuran (in French). Arch Int Pharmacodyn Ther 1962;139:247-254.

-5 Munoz Ruiz AI, Calvo Elipe A, Guerrero Vega E, Gorgojo Martinez JJ, Vera Lopez E, Gilsanz Fernandez C: Pancreatitis and inappropriate ADH secretion syndrome associated with amiodarone (in Spanish). An Med Interna 1996;13:125-126.

6 Aslam MK, Gnaim C, Kutnick J, Kowal RC, McGuire DK: Syndrome of inappropriate antidiuretic hormone secretion induced by amiodarone therapy. Pacing Clin Electrophysiol 2004;27:831-832.

7 Ikegami H, Shiga T, Tsushima T, Nirei T, Kasanuki H: Syndrome of inappropriate antidiuretic hormone secretion (SIADH) induced by amiodarone: a report on two cases. J Cardiovasc Pharmacol Ther 2002;7: $25-28$.

$>8$ Odeh M, Schiff E, Oliven A: Hyponatremia during therapy with amiodarone. Arch Intern Med 1999;159:2599-2600.

-9 Patel GP, Kasiar JB: Syndrome of inappropriate antidiuretic hormone-induced hyponatremia associated with amiodarone. Pharmacotherapy 2002;22:649-651.

10 Paydas S, Araz F, Balal M: SIADH induced by amiodarone in a patient with heart failure. Int J Clin Pract 2008;62:337.

11 Shavit E, Sherer Y: Hyponatremia induced by amiodarone therapy. Isr Med Assoc J 2007;9:564-565.

-12 Singla S, Strobel AL, Deshmukh AJ, Paydak H: Amiodarone-related hyponatremia: rare but potentially lethal. Am J Ther 2011, E-pub ahead of print.

13 Afshinnia F, Sheth N, Perlman R: Syndrome of inappropriate antidiuretic hormone in association with amiodarone therapy: a case report and review of literature. Ren Fail 2011;33:456-458.

14 Belton K, Thomas SH: Drug-induced syndrome of inappropriate antidiuretic hormone secretion. Postgrad Med J 1999;75:509-510.

15 Liu BA, Mittmann N, Knowles SR, Shear NH: Hyponatremia and the syndrome of inappropriate secretion of antidiuretic hormone associated with the use of selective serotonin reuptake inhibitors: a review of spontaneous reports. CMAJ 1996;155:519-527.

-16 Gill G, Huda B, Boyd A, Skagen K, Wile D, Watson I, van Heyningen C: Characteristics and mortality of severe hyponatraemia - a hospital-based study. Clin Endocrinol (Oxf) 2006;65:246-249. 


\begin{tabular}{l|l}
\hline DOI: 10.1159/000350910 & $\begin{array}{l}\text { ○ 2013 S. Karger AG, Basel } \\
\text { www.karger.com/cru }\end{array}$ \\
\hline
\end{tabular}

Pham et al.: Hyponatremia - A Rare but Serious Complication of Amiodarone: A Case

Report and Review of the Literature

Table 1. Summary of the 10 cases of SIADH induced by amiodarone reported in the literature, including the present case

\begin{tabular}{|c|c|c|c|c|c|c|}
\hline First author & $\begin{array}{l}\text { Age/ } \\
\text { sex }\end{array}$ & Doses of amiodarone & $\begin{array}{l}\text { Lowest } \\
\text { sodium level } \\
\mathrm{mmol} / \mathrm{l}\end{array}$ & $\begin{array}{l}\text { Time to } \\
\text { l develop } \\
\text { hyponatremia }\end{array}$ & Treatment & $\begin{array}{l}\text { Day until serum } \\
\text { sodium level } \\
\text { normalized }\end{array}$ \\
\hline Munoz Ruiz [5] & $67 / F$ & NA & 110 & 4 months & $\mathrm{D} / \mathrm{C}$ & Unknown \\
\hline Odeh [8] & $62 / \mathrm{F}$ & $300 \mathrm{mg} \mathrm{qd}$ & 120 & 6 months & $\mathrm{D} / \mathrm{C}$ & 5 days \\
\hline Patel [9] & $67 / \mathrm{M}$ & $200 \mathrm{mg} \mathrm{qd}$ & 117 & 3 months & Fluid restriction $+\mathrm{D} / \mathrm{C}$ & 3 days \\
\hline \multirow[t]{2}{*}{ Ikegami [7] } & $63 / \mathrm{M}$ & $800 \mathrm{mg} \mathrm{qd}$ & 119 & 7 days & Decrease to $100 \mathrm{mg}$ + fluid restriction & 28 days \\
\hline & $82 / \mathrm{M}$ & $200 \mathrm{mg} \times 7$ days and $100 \mathrm{mg} \mathrm{qd}$ & 121 & 15 days & $\begin{array}{l}\text { Continue } 100 \mathrm{mg} \text { qd + fluid } \\
\text { restriction }\end{array}$ & 14 days \\
\hline Aslam [6] & $72 / \mathrm{M}$ & $2 \mathrm{gqd}$ & 117 & 5 days & Decrease dose to $200 \mathrm{mg}$ qd & 14 days \\
\hline Shavit [11] & $85 / \mathrm{M}$ & NA & 122 & 30 days & $\mathrm{D} / \mathrm{C}$ & A few days \\
\hline Paydas [10] & $58 / \mathrm{M}$ & NA & 107 & 5 months & $\mathrm{D} / \mathrm{C}$ & 14 days \\
\hline Singla [12] & $58 / \mathrm{M}$ & $1,600 \mathrm{mg} \mathrm{qd}$ & 120 & 3 days & $\mathrm{D} / \mathrm{C}$ and dialysis & \\
\hline Afshinnia [13] & $66 / \mathrm{M}$ & $\begin{array}{l}\text { IV } 150 \mathrm{mg} \text { bolus then } 900 \mathrm{mg} \\
\text { drip then 1,200 mg PO qd }\end{array}$ & 116 & 7 days & $\mathrm{D} / \mathrm{C}$ & 16 days \\
\hline $\begin{array}{l}\text { Pham et al. [this } \\
\text { report] }\end{array}$ & $84 / \mathrm{M}$ & $\begin{array}{l}\text { IV } 150 \mathrm{mg} \text { bolus + drip, then PO } \\
1,200 \mathrm{mg} \times 7 \text { days then } 400 \mathrm{mg} \\
\mathrm{gd}\end{array}$ & 105 & 11 days & $\begin{array}{l}\mathrm{D} / \mathrm{C}+3 \% \mathrm{NaCl} \times 3 \text { days then fluid } \\
\text { restriction }+ \text { demeclocycline }\end{array}$ & 10 days \\
\hline
\end{tabular}

qd = Daily; NA = not available; $\mathrm{D} / \mathrm{C}=$ amiodarone discontinued.

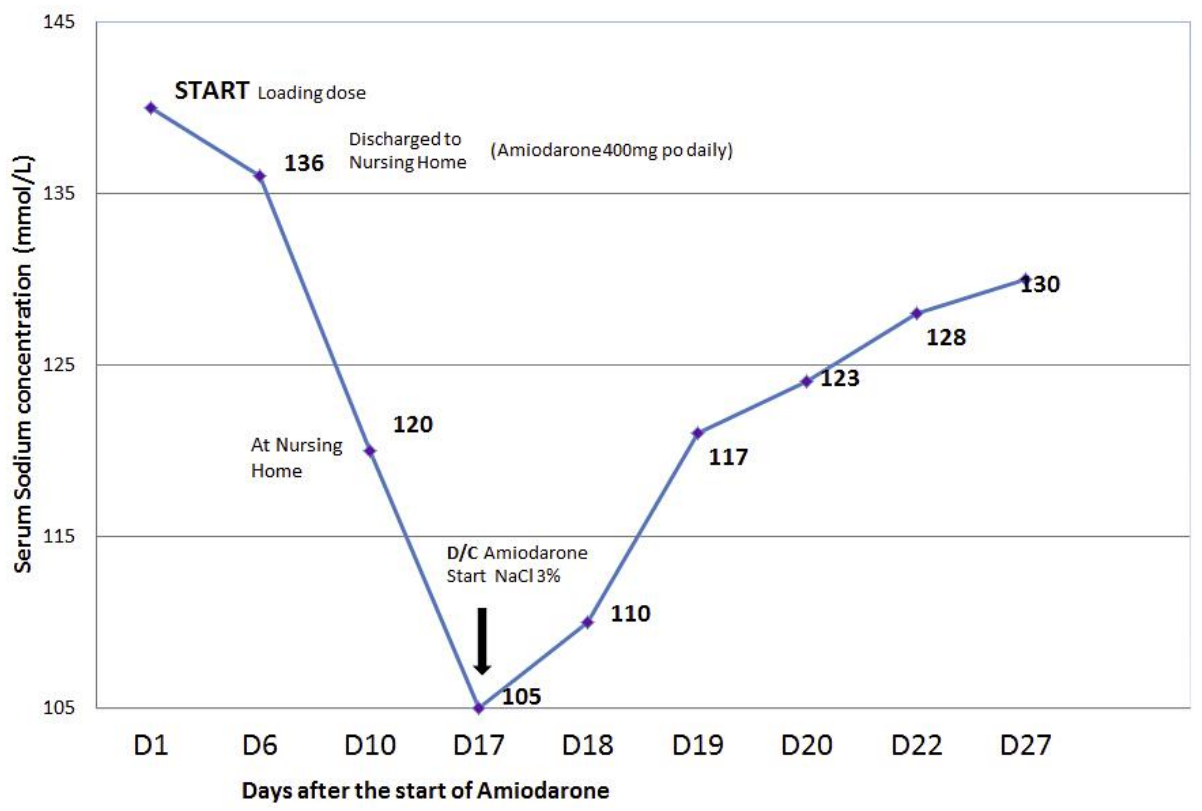

Fig. 1. Change in the serum sodium concentration with time. Note the serum sodium level nadir on day 17. 